\title{
Do Political Connections Affect Bank Loan Loss Provision Reliability?
}

\author{
Qiuhong Zhao ${ }^{1}$ \\ ${ }^{1}$ Assistant Professor of Accounting, College of Business, OCNR 352, Texas A\&M University-Corpus Christi, 6300 \\ Ocean Drive Unit 5808, Corpus Christi, Texas 78412, USA \\ Correspondence: Qiuhong Zhao, Assistant Professor of Accounting, College of Business, OCNR 352, Texas A\&M \\ University-Corpus Christi, 6300 Ocean Drive Unit 5808, Corpus Christi, Texas 78412, USA. Tel: 1-361-825-3619 \\ Fax: 361-825-5609
}

Received: July 12, 2016

Accepted: August 4, 2016

Online Published: August 7, 2016

doi:10.5430/afr.v5n3p118

URL: http://dx.doi.org/10.5430/afr.v5n3p118

\begin{abstract}
This study examines whether political connections affect the loan loss provision (LLP) quality of financial institutions, in particular LLP reliability. Using a geography-based measure, I document that politically connected banks have more reliable LLP than do non-connected banks, consistent with the fact that politically connected banks are subject to more extensive controls than non-politically connected banks. Thus, political connections are more likely to be associated with reliable LLP. In addition, I document that the effect of improved political connections on reliability is more pronounced in the subsamples of banks with investment grades relative to the subsamples of banks with noninvestment grades. Finally, the effect of political connections on reliability is more pronounced in the subsample of banks in the expansion periods relative to the recession periods. These findings are consistent with the argument that connected banks did not engage in improving LLP quality for predicting future loan defaults as they might have relied on receiving support from the government in lieu of expending their resources.
\end{abstract}

Keywords: Political connections, LLP reliability, Recessions

\section{Introduction}

The literature provides evidence that firms with political involvement receive favors and support in return. For example, the Securities and Exchange Commission (SEC) had returned favors to politically connected firms by issuing less enforcement actions, lowering lobby costs and reducing penalties imposed by an enforcement action (Correia, 2014). Firms with political involvement do not have strong motivation to improve their financial reporting quality because they face less pressure from monitoring agencies (Chaney, Faccio, and Parsley, 2011). The efficacy of banks' financial reporting during the 2008-2009 financial crisis has been questioned. Would the monitoring agencies exert extensive control over political connected banks to improve their loan loss provision quality to benefit investors?

This study examines whether political connections affect loan loss provision (LLP) reliability in the banking industry. Several finance studies have documented that politically connected banks are more likely to receive support from the government in times of economic distress (Blau, Brough, \&Thomas, 2013); thus these banks are more likely to engage in risk taking activities (Kostovesky, 2015). Bank failure is about $45 \%$ less likely in the year leading up to an election, perhaps to avoid the political costs associated with failure (Liu \& Ngo, 2014). Moreover, Chaney et al. (2011) have found that politically connected firms with poor accounting information do not suffer higher cost of debt, consistent with the argument that political connections mitigate the costs of poor accounting information. Boubakri, Guedhami, Mishra, \& Saffar (2012) noted that politically connected banks are more likely to enjoy lower capital costs. In a similar vein, Houston et al. (2014) have documented that the politically connected firms are more likely to receive favorable terms for bank loans because banks recognize that political connections enhance borrowers' credit worthiness. My study is motivated not only by the stream of literature on bank lending practices but also by the large number of small banks and the segmented nature of US bank regulation. Since LLP is identified as the largest operating accrual (Beatty \& Liao, 2014), I focus on this provision to capture banks' financial reporting quality. Both the Office of Comptroller for Currency (OCC) and the Securities and Exchange Commission provide clear guidance on the methodologies for estimating loan losses, indicating that LLP reliability is an important measure of financial reporting quality. 
My primary hypothesis is that politically connected banks are associated with more reliable LLP because these banks are subject to extensive controls and monitoring (including scrutiny by the media) (Chaney et al., 2011). For example, public financial institutions are required to file their financial statements with several authorities, including the SEC. However, Chaney et al.'s evidence has suggested that connected nonfinancial firms are not concerned about earnings quality as much as non-connected firms. Therefore, whether connected banks are positively associated with reliable LLP is an empirical question, due to the uniqueness of the bank sector. In addition, I hypothesize that the potential effect of political connections on LLP reliability might be more pronounced when connected banks seek/receive political favor, e.g., bailouts, because they do not have resources to improve LLP reliability, which might be costly. During recession periods, connected banks might need to allocate more resources to improve their operations than to engage in activities to improve LLP reliability. In a similar vein, banks with noninvestment ratings might need to allocate to improve key financial ratios, thus reducing credit risk, rather than engaging in activities to improve LLP reliability.

Following Kostovesky (2015), I employ a geography-based measure, Senate Banking Committee representation (an indicator), to proxy for political connections. Historical membership of the Senate Banking Committee is manually collected from annual volumes of the Official Congressional Directory. For each financial institution and year, I define an indicator variable Committee Senator as equaling one if the institution is headquartered in a state with a senator on the Banking Committee in that year, and zero otherwise. Kostovesky (2015) argued that this senate bank representation is a better proxy than the other proxies (e.g., lobby expenditures) to measure political connections, due to the power of senators over government officials overseeing the banking industry and due to its exogenous nature. To test my primary hypothesis, I estimate the reliability model (Kilic, Lobo, Ranasinghe, \& Sivaramakrishnan, 2013), using the current-year LLP to predict future loan defaults (i.e., charge offs), after controlling for size, in the sample period spanning from 1997 to 2015. Then, I partition my sample into subsamples to test whether the effects of political connects on LLP reliability differ.

This study provides three important inferences. First, I document that politically connected banks have more reliable LLP than do non-connected banks. This finding is consistent with the fact that politically connected banks are subject to more extensive controls than non-politically connected banks. Thus, political connections are more likely to be associated with reliable LLP. In addition, I document that the improvement of political connections on reliability is more pronounced in the subsamples of banks with investment grades relative to the subsamples of banks with noninvestment grades. Finally, the improvement of political connections on reliability is more pronounced in the subsamples of banks in the expansion periods relative to the recession periods. These findings are consistent with the argument that connected banks did not engage in improving LLP quality for predicting future loan defaults as they might have relied on receiving support from the government in lieu of expending their resources.

In sum, my findings are consistent with my (alternative) hypotheses. My study is unique in examining the effect of political connections on financial reporting quality in a sample period that includes the global financial crisis of 2008. Therefore, this paper has important implications for the regulation of the US financial system in terms of costs and benefits of political connections.

The rest of the paper proceeds as follows. Section 2 reviews the literature. Section 3 states my hypotheses. Section 4 discusses data, sample selection and research design. Section 5 presents results. Section 6 concludes the study.

\section{Literature Review}

A stream of finance research hasexamined the economic benefits of political connections for firms that lobby or maintain other types of political connections (Boubakri et al., 2012, Cooper, Gulen, \& Ovtchinnikov, 2010, Faccio \& Parsley, 2009, Fisman, 2001, Hill, Kelly, Lockhart, \& Van Ness 2013, Hochberg, Sapienza, \& Vissing-Jorgensen, 2009, Igan, Mishra, \&Tressel, 2009, Jayachandran, 2006, Richter, Samphantharak, \&Timmmons, 2009, Stratmann, 1991, Roberts, 1990, Yu \&Yu, 2011). In particular, the literature provides evidence that engagement in the political process might be used as a form of insurance against financial crises. For example, politically connected firms are more likely to receive support from the government in times of economic distress (Faccio et al., 2006, Blau et al., 2013); thus, these banks are more likely to engage in risk taking activities (Kostovesky, 2015). In addition, Blau et al. (2013) provided evidence that politically engaged banks also received a greater amount of 2008 Troubled Asset Relief Program (TARP); thus, these banks were less likely to become bankrupt in the economic crises. Finally, Correia (2014) provided evidence that firms connected with SEC are less likely to receive enforcement actions and to pay fewer penalties.

On the other hand, only a few studies have examined the consequences of political engagements on financial reporting quality. For instance, Chaney et al. (2011) have found that politically connected firms with poor accounting 
information do not suffer higher cost of debt measured as the average realized cost of total debt and the yield to maturity spread on public debt, which is consistent with the argument that political connections mitigate the costs of poor accounting information measured as discretionary accruals. They argued that "because of a lesser need to respond to market pressures to increase the quality of information, connected companies can afford disclosing lower quality accounting information" (abstract, p.58).

A stream of accounting literature has document that LLP provides incremental information about the future performance of loan portfolios beyond the information conveyed by supplemental disclosures (e.g., Gambera, 2000, Nichols, Wahlen, \& Wieland, 2009, Beatty \& Liao, 2011, Bushman \& Williams 2012, 2013, Bushman, Hendricks, \& Williams, 2015, Bhat et al. 2014a,b). Several accounting studies have explored factors affecting LLP quality. For example, Kilic et al. (2013) examined the impact of SFAS 133, Accounting for Derivative Instruments and Hedging Activities, on the informativeness of their financial statements. In particular, they found that the increased reliance on loan loss provisions for smoothing income after the implementation of fair value accounting on derivatives has impaired the informativeness of loan loss provisions for future loan defaults and bank stock returns. In addition, Dou, Ryan, \&Zou (2015) have provided evidence that deregulation in the banking industry has affected LLP quality. Chaney et al. (2011) excluded financial institutions from their sample. My study extends Chaney et al. (2011) by examining the effect of political connections on the informativeness of current period LLP for future loan defaults in the US banking industry. The banking industry has become intensively regulated and monitored (including media security) by different authorities. The chartering authority for national banks is the OCC, while state banks are chartered by state regulators.

This study contributes to current literature on the connections among financial reporting quality, political connections, and government intervention. Specifically, this study builds on Chaney et al. (2011) by providing empirical evidence for linkages between political connections and financial reporting quality. While Chaney et al. focus on earnings quality measured as discretionary accruals in an international setting, I focus on the informativeness of current period LLP for future loan defaults in the US banking industry. As the banking industry has become intensively regulated and monitored, my findings reflect this change in banking and thus differ from those of Chaney et al. (2011). My study is unique in examining the effect of political connections on financial reporting quality in a sample period that includes the global financial crisis of 2008.

\section{Research Question and Hypothesis Development}

This study investigates whether political connections affect LLP reliability in the banking industry. Given the reliance of both investors and financial intermediaries on accurate financial reporting, I focus on the role of banks' financial reporting in risk assessment. The OCC and the SEC provide clear guidance on the methodologies for estimating loan losses, indicating that LLP reliability is an important measure of financial reporting quality. The SEC recommends that banks review the trends in loan volume, delinquencies, restructurings, concentrations, and charge-off and recovery history in order to develop a reasonable loan loss allowance methodology. LLP estimates are usually based on average historical default rates by different levels of borrowers (that is, the incurred loss model). Clearly, the process for estimating reliable LLP is time-consuming and costly. Compared to non-connected banks, connected banks might be more likely to engage costly information collection to provide more reliable LLP information under the intensive controls and monitoring previously noted. As a result, my primary hypothesis is that politically connected banks are associated with more reliable LLP because these banks are subject to extensive controls and monitoring (including scrutiny by the media) (Chaney et al., 2011). However, Chaney et al.'s evidence suggests that connected nonfinancial firms might not be concerned about earnings quality as much as non-connected firms. Therefore, whether connected banks are positively associated with reliable LLP is an empirical question, due to the uniqueness of the bank sector. My first hypothesis is (in an alternative form):

H1: Politically connected banks are associated with more reliable LLP.

Furthermore, I hypothesize that the potential effect of political connections on LLP reliability might be more pronounced, because, when connected banks seek/receive funds from the government, they do not have resources to improve LLP reliability. In particular, connected banks might revise the priority of resource allocation in times of crises. During recession periods, connected banks might seek to improve their performance through resource allocation more than through loan loss estimation methodologies to improve LLP reliability. In other words, the potential effect of political connections on LLP reliability might be more pronounced in expansion periods than in recession periods. Accordingly, my second hypothesis is (in an alternative form):

$\mathrm{H} 2$ : The effect of political connections on reliability is more pronounced in the subsample of banks in the expansion periods relative to the recession periods. 
In a similar vein, bank credit risk might play a significant role in the effect of political connection on LLP reliability. This study argues that banks with noninvestment ratings, unlike banks with investment ratings, might prefer to allocate more funds, perhaps received from the government, in order to improve their key financial ratios rather than to engage in activities that would improve their LLP reliability. As a result, the potential effect of political connections on LLP reliability might be more pronounced for banks with investment ratings (less credit risk) than for banks with noninvestment ratings (greater credit risk). Accordingly, my third hypothesis is (in an alternative form):

H3: The effect of political connections on reliability is more pronounced in the subsamples of banks with investment grades relative to the subsamples of banks with noninvestment grades.

\section{Data, Sample Selection, and Research Design}

\subsection{Data and Sample Selection}

My sample period spans 1997 to 2015, including two recession periods: 2001 Q2-Q4 and 2008 Q1-2009 Q2. I obtain bank annual financial data, geography data, long-term issuer rating data from Compustat Bank files. I start with 19,815 observations in the Compustat banks files for the sample period. Historical membership of the Senate Banking Committee is manually collected from annual volumes of the Official Congressional Directory. I identify 400 state year observations with a senator on the Banking Committee for the period 1997 to 2015 . After merger of both sources of data, the resulting sample is 12,391 bank year observations. After deletion of observations without necessary control variable data (1,056 observations), the final sample consists of 11,335 bank year observations.

\subsection{Research Design}

To test my primary hypothesis, I estimate the following LLP reliability regression (Kikic et al., 2013):

$$
\begin{aligned}
& \text { ChargeOffs }_{i, t+1}=\alpha_{0}+\alpha_{1} \text { LLP }_{i, t}+\alpha_{2} \text { Committee_Senator }_{i, t}+\alpha_{3} L_{L P} P_{i, t} * \text { Committee_Senator }_{i, t} \\
& +\alpha_{4} \text { NonPerform }_{i, t}+\alpha_{5} \text { Size }_{i, t}+\varepsilon_{i, t+1}
\end{aligned}
$$

Where (Compustat data code is reported in parentheses)

ChargeOffs $s_{i, t+1}$ : net loan charge-offs (nco) at year $t+1$ scaled by beginning total loans (lntal) at year $t+1$.

$L L P_{i, t}$ : loan loss provision (pll) at year $t$ scaled by total loans (lntal) at year $t$.

Committee_Senator ${ }_{i, t}:=1$ if the institution is headquartered in a state with a senator on the Banking Committee at year $t ;=0$ otherwise (Following Kostovesky, 2015).

NonPerform $_{i, t}$ : nonperforming loans (npat) at year $t$ scaled by total loans (lntal) at year $t$.

Size $_{i, t}$ : natural logarithm of total assets (at)at year $t$.

Kostovesky (2015) argued that this senate bank representation is a better proxy than the other proxies (e.g., lobby expenditures) for measuring political connections due to the power of senators over government officials who oversee the banking industry and due to its exogenous nature. $L L P_{i, t}{ }^{*}$ Committee_Senator is the variable of interest. I expect $\alpha_{3}$ to be positive (negative) if politically connected banks report more reliable (less reliable) LLP than non-connected banks. I do not make any predictions on the control variables, nonperforming loans, and size. In an alternative specification, earnings before taxes and LLP (pi) is included in the regression to control for income smoothing. I computed standard errors after adjusting for state clustering.

To test whether the effects of political connects on LLP reliability are different in different economic periods, I partition my sample into two subsamples: the recession group (observations in years 2001, 2008, and 2009) and the expansion group (observations in the other years in my sample period 1997-2015). Then, I estimate model (1) using the two subsamples separately. In addition, I test whether the effects of political connections on LLP reliability are different for banks with different credit risk. Based on the long term issuer ratings, I partition my sample into subsamples: observations with investment grades (greater or equal to BBB-) and observations with noninvestment grades (less than BBB-). Then, I estimate model (1) using the two subsamples separately. (Note 1)

\section{Results}

\subsection{Descriptive Statistics}

Table 1 presents the summary statistics for variables used in estimating Model (1) for both the politically connected group and the non-connection group. The two groups have the similar size and nonperforming loans on average. However, the average chargeoff in the connection group, -0.004 , is significantly greater than that in the control group at the one percent level, whereas the average LLP in the connection group is significantly lower than that in the control group. Table 2 presents the correlation of variables included in the LLP reliance model. Next year Chargeoff 
is negatively correlated with Current year $L L P$, nonperforming loans, and firm size at the one percent level. However, there is a significantly positive correlation $(0.04, \mathrm{P}$ value $<0.0001)$ between the political connection indicator, Committee_Senator, and Chargeoff.

Table 1. Descriptive Statistics

\begin{tabular}{lllll}
\hline Committee_Senator & N Obs & Variable & Mean & Median \\
\hline 0 & 5968 & Chargeoff & -0.005 & -0.002 \\
& & Size & 6.973 & 6.715 \\
& LLP & 0.006 & 0.003 \\
& & Nonperform & 0.018 & 0.009 \\
\hline 1 & 5367 & Chargeoff & $-0.004^{* * *}$ & -0.002 \\
& & Size & 6.971 & 6.691 \\
& LLP & $0.005^{* *}$ & 0.003 \\
& Nonperform & 0.018 & 0.010
\end{tabular}

$* * *, * *, \overline{\text { and }}$ * indicate significance at the one percent, five percent, and one percent respectively (two-tailed test).

Table 2. Pearson Correlation

\begin{tabular}{llllll}
\hline & Chargeoff & Size & LLP & Nonperform & Committee_Senator \\
\hline Chargeoff & 1 & & & & \\
Size & -0.194 & 1 & & & \\
& $<.0001$ & & & & \\
LLP & -0.704 & 0.154 & 1 & & \\
& $<.0001$ & $<.0001$ & & & 1 \\
Nonperform & -0.558 & 0.035 & 0.613 & 1 & \\
& $<.0001$ & 0.000 & $<.0001$ & & \\
Committee_Senator & 0.040 & -0.001 & -0.023 & -0.006 & \\
& $<.0001$ & 0.951 & 0.015 & 0.515 &
\end{tabular}

\section{$5 . 2 \longdiv { \text { Reliability Regression Results } }$}

Table 3 presents the primary results of estimating Model (1) and computing standard errors adjusted for state clustering. The estimated coefficient on LLP, -0.528 , is significantly negative at the one percent level (two-tailed test, $\mathrm{t}$-stat $=-33.86$ ), suggesting on average current-year $L L P$ does not predict next year Chargeoffs well. More importantly, the results that the estimated coefficient on the interaction variable, 0.034 , is significantly positive at the five percent level (two tailed test, $t$-stat $=2.11$ ), support my primary hypothesis: politically connected banks have more reliable LLP than do non-connected banks since politically connected banks are subject to more extensive controls than non-politically connected banks. In other words, the results suggest that political connections are more likely to be associated with reliable LLP. The estimated coefficients on both the nonperforming loan variable and size are significantly negative at the one percent level. 
Table 3. Results of Estimating the LLP Reliability Model

\begin{tabular}{lllll}
\hline Variable & Estimate & $\begin{array}{l}\text { Clustered } \\
\text { Standard Error }\end{array}$ & $\begin{array}{l}\text { t Value } \\
\text { (two tailed test) }\end{array}$ & \begin{tabular}{l}
$\operatorname{Pr}>|\mathrm{t}|$ \\
\hline Intercept
\end{tabular} \\
LLP & $0.003^{* * *}$ & 0.000 & $(13.22)$ & $<.0001$ \\
Committee_Senator & $-0.528^{* * *}$ & 0.016 & $(-33.86)$ & $<.0001$ \\
LLP*Committee_Senator & 0.000 & 0.000 & $(1.09)$ & 0.279 \\
Nonperform & $0.035^{* *}$ & 0.016 & $(2.11)$ & 0.040 \\
Size & $-0.066^{* * *}$ & 0.005 & $(-13.17)$ & $<.0001$ \\
$\#$ of observation & $-0.001^{* * *}$ & 0.000 & $(-14.63)$ & $<.0001$ \\
$\mathrm{R}^{2}$ & 11,335 & & & \\
\hline
\end{tabular}

***, ${ }^{* *}$, and $*$ indicate significance at the one percent, five percent, and one percent respectively (two-tailed test).

Table 4 presents the results of estimating Model (1) in the different periods, recessions vs. expansions. Panel A presents the results for the bank year observations in recession periods (1986 obs.), while panel B presents the results for the bank year observations in expansion periods (9,349 obs.). A notable difference lies in the magnitude of the estimated coefficient on the interaction term. The estimated coefficient on the interaction term for the recession observations is only 0.0087 , compared to 0.0148 for the expansion observations, although neither is statistically significant. However, I suspect that the insignificance of the estimated coefficients for the subsamples is due to the smaller sample size. The results suggest that the improvement of political connections on reliability is more pronounced in the subsample of banks in the expansion periods relative to the recession periods.

Table 4. Results of Estimating the LLP Reliability Model in Economic Periods

Panel A: Results in recession periods

\begin{tabular}{|c|c|c|c|c|}
\hline Variable & Estimate & $\begin{array}{l}\text { Clustered } \\
\text { Standard Error }\end{array}$ & $\begin{array}{l}\text { t Value } \\
\text { (two tailed test) }\end{array}$ & $\operatorname{Pr}>|t|$ \\
\hline Intercept & $0.005 * * *$ & 0.001 & 5.49 & $<.0001$ \\
\hline$L L P$ & $-0.648 * * *$ & 0.039 & -16.41 & $<.0001$ \\
\hline Committee_Senator & $0.001 * * *$ & 0.001 & 2.88 & 0.005 \\
\hline$L L P^{*}$ Committee_Senator & 0.009 & 0.047 & 0.18 & 0.854 \\
\hline Nonperform & $-0.145^{* * *}$ & 0.022 & -6.53 & $<.0001$ \\
\hline Size & $-0.001 * * *$ & 0.000 & -8.83 & $<.0001$ \\
\hline \# of observation & 1,986 & & & \\
\hline $\mathrm{R}^{2}$ & 0.589 & & & \\
\hline \multicolumn{5}{|c|}{ Panel B: Results in expansion periods } \\
\hline Variable & Estimate & $\begin{array}{l}\text { Clustered } \\
\text { Standard Error }\end{array}$ & $\begin{array}{l}\text { t Value } \\
\text { (two tailed test) }\end{array}$ & $\operatorname{Pr}>|t|$ \\
\hline Intercept & $0.002 * * *$ & 0.000 & 10.98 & $<.0001$ \\
\hline$L L P$ & $-0.466^{* * *}$ & 0.015 & -31.95 & $<.0001$ \\
\hline Committee_Senator & 0.000 & 0.000 & -0.35 & 0.729 \\
\hline$L L P^{*}$ Committee_Senator & 0.015 & 0.015 & 1.02 & 0.3126 \\
\hline Nonperform & $-0.067 * * *$ & 0.005 & -13.00 & $<.0001$ \\
\hline Size & $0.000 * * *$ & 0.000 & -11.36 & $<.0001$ \\
\hline \# of observation & 9,349 & & & \\
\hline $\mathrm{R}^{2}$ & 0.574 & & & \\
\hline
\end{tabular}


Table 5 presents the results of estimating Model (1) for two groups, banks with and without investment grades. Panel A presents the results for the banks with investment grades ( 892 obs.), while panel B presents the results for the banks with noninvestment grades ( 92 obs.). The estimated coefficient on the interaction term for the recession observations is only 0.0201 , compared to 0.0901 for the expansion observations. Both of the estimates are significant, at least at the five percent level. The results suggest that the improvement of political connections on reliability is more pronounced in the subsample of banks with investment grades relative to the subsample of banks with noninvestment grades. Taken together, the results presented in tables 4 and 5 are consistent with the argument that connected banks did not engage in improving LLP quality for predicting future loan defaults as they might have relied on receiving support from the government in lieu of expending their resources. Overall, the findings are consistent with my predictions described in Section 2.

Table 5. Results of Estimating the LLP Reliability Model based on Credit Risk

Panel A: Results for the group with investment grades

\begin{tabular}{lllll}
\hline Variable & Estimate & $\begin{array}{l}\text { Clustered } \\
\text { Standard Error }\end{array}$ & $\begin{array}{l}\mathrm{t} \text { Value } \\
\text { (two tailed test) }\end{array}$ & Pr $>|\mathrm{t}|$ \\
\hline Intercept & $0.005^{* * *}$ & 0.001 & 3.71 & 0.001 \\
LLP & $-0.720^{* * *}$ & 0.075 & -9.59 & $<.0001$ \\
Committee_Senator & 0.000 & 0.000 & -1.06 & 0.296 \\
LLP*Committee_Senator & $0.090^{* *}$ & 0.041 & 2.18 & 0.037 \\
Nonperform & -0.018 & 0.045 & -0.39 & 0.697 \\
Size & $-0.001^{* * *}$ & 0.000 & -4.67 & $<.0001$ \\
\# of observation & 892 & & & \\
$\mathrm{R}^{2}$ & 0.645 & & & \\
\hline
\end{tabular}

\begin{tabular}{lllll}
\hline \multicolumn{4}{l}{ Panel B: Results for the group with noninvestment grades } \\
\hline Variable & Estimate & $\begin{array}{l}\text { Clustered } \\
\text { Standard Error }\end{array}$ & $\begin{array}{l}\text { t Value } \\
\text { (two tailed test) }\end{array}$ & \\
\hline Intercept & & 0.006 & 0.910 & 0.378 \\
LLP & 0.005 & 0.117 & -5.660 & $<.0001$ \\
Committee_Senator & $-0.661^{* * *}$ & 0.002 & -0.410 & 0.690 \\
LLP*Committee_Senator & -0.001 & 0.007 & 3.270 & 0.005 \\
Nonperform & $0.022^{* * *}$ & 0.023 & -1.700 & 0.108 \\
Size & -0.038 & 0.001 & -1.180 & 0.253 \\
\# of observation & -0.001 & & & \\
$\mathrm{R}^{2}$ & 92 & & & \\
\hline
\end{tabular}

***, **, and * indicate significance at the one percent, five percent, and one percent respectively (two-tailed test).

\section{Conclusion}

This study documents that LLP is systematically more reliable to predict future loan defaults (i.e., chargeoffs) for banks with political connections than for firms lacking such connections, which is consistent with the control and monitoring hypothesis. That is, because political connected banks are subject to extensive controls and monitoring, banks with political connections would develop more reasonable and accurate loss estimation methodologies, which provides more reliable loan losses estimates to reflect future charge off. In addition, I document that the effect of political connections on reliability is more pronounced in bank-year observations with investment grades relative to the observations with noninvestment grades. Finally, I find that the effect of political connections on reliability is more pronounced in the subsample of banks in the expansion periods relative to the recession periods.

My findings are consistent with the conjecture that connected banks did not engage in improving LLP quality for predicting future loan defaults as they might have relied on receiving support from the government in lieu of 
expending their resources. Political connected banks seem more concerned with financial reporting quality, unlike politically connected firms in other industries, possibly due to the stricter monitoring regulation system in the banking industry. This study provides insight in the costs and benefits of political connections. Future research might investigate the effect of political investment on other features of LLP, such as timeliness to record charge-offs and recoveries.

\section{Acknowledgement}

This research was partially supported by 2016 research enhancement grant from the College of Business at Texas A\&M University-Corpus Christi.

\section{References}

Beatty, A., \& Liao, S. (2011). Do delays in expected loss recognition affect banks' willingness to lend? Journal of Accounting and Economics, 52, 1-20. http://dx.doi.org/10.1016/j.jacceco.2011.02.002

Beatty, A., \& Liao, S. (2014). Financial accounting in the banking industry: A review of the empirical literature. Journal of Accounting and Economics, 58, 339-383. http://dx.doi.org/10.1016/j.jacceco.2014.08.009

Bhat, G., J. Lee, and S. Ryan. (2014b). Utilizing Loan Loss Indicators by Loan Type to Sharpen the Evaluation of the Determinants and Implications of Banks' Loan Loss Accruals. Working paper, Southern Methodist University.

Bhat, G., S. Ryan, \& D. Vyas. (2014a). The implications of credit risk modeling for banks' loan loss provision timeliness and loan origination procyclicality. Working paper, New York University.

Blau, M.B., Brough, I. T., \& Thomas, W. D. (2013). Corporate lobbying, political connections, and the bailout of banks. Journal of Banking \& Finance, 37, 3007-3017. http://dx.doi.org/10.1016/j.jbankfin.2013.04.005

Boubakri, N., Guedhami, O., Mishra, D., \& Saffar, W. (2012). Political connections and the cost of equity capital. Journal of Corporate Finance, 18, 541-559. http://dx.doi.org/10.1016/j.jcorpfin.2012.02.005

Bushman, R., \& Williams, C. (2012). Accounting discretion, loan loss provisioning, and discipline of banks' risk-taking. Journal of Accounting and Economics, 54, 1-18. http://dx.doi.org/10.1016/j.jacceco.2012.04.002

Bushman, R., Hendricks, B., \& Williams, C. (2015). Bank competition: Measurement, decision making, and risk profiles. Ross School of Business Working paper No. 1243.

Chaney, P.K., Faccio, M., \& Parsley, D. (2011). The quality of accounting information in politically connected firms. Journal of Accounting and Economics, 51, 58-76. http://dx.doi.org/10.1016/j.jacceco.2010.07.003

Cooper, M. J., Gulen, H., \& Ovtchinnikov, A.V. (2010). Corporate political contributions and stock returns. Journal of Finance, 65(2), 687-724. http://dx.doi.org/ 10.1111/j.1540-6261.2009.01548.x.

Correia, M. M. (2014). Political connections and SEC enforcement. Journal of Accounting and Economics, 57, 241-262. http://dx.doi.org/10.1016/j.jacceco.2014.04.004

Dou,Y., Ryan, S., \& Zou, Y. (2015). The effects of credit competition on banks' loan loss provisions. Working paper. New York University and George Washington University.

Faccio, M. (2006). Politically connected firms. American Economic Review, 96, 369-386. http://dx.doi.org/10.1257/000282806776157704

Faccio, M., \& Parsley, D.C. (2009). Sudden deaths: taking stock of geographic ties. Journal of Financial and Quantitative Analysis, 44(3), 683-718. http://dx.doi.org/10.1017/S0022109009990068

Faccio, M., Masulis, R., \& McConnell, J. (2006). Political connections and corporate bailouts. Journal of Finance, 61, 2597-2635. http://dx.doi.org/10.1111/j.1540-6261.2006.01000.x.

Fisman, R. (2001). Estimating the value of political connections. American Economic Review, 91(4), 1095-1102. http://dx.doi.org/10.1257/aer.91.4.1095

Gambera, M. (2000). Simple forecasts of bank loan quality in the business cycle. Working Paper. Federal Reserve Bank of Chicago.

Hill, M., Kelly, G.W., Lockhart, B., \& Van Ness, R. (2013). Determinants and effects of corporate lobbying. Financial Management. http://dx.doi.org/10.1111/fima.12032

Hochberg, Y., Sapienza, Y., \& Vissing-Jorgensen, A. (2009). A lobbying approach to evaluating the Sarbanes-Oxley Act of 2001. Journal of Accounting Research, 47, 519-583. http://dx.doi.org/10.1111/j.1475-679X.2009.00321.x 
Houston, F.J., Jiang, L, Lin, C., \& Ma, Y., (2014). Political connections and the cost of bank loans. Journal of Accounting Research, 52, 193-240. http://dx.doi.org/10.1111/1475-679X.12038

Igan, D., Mishra, P., \& Tressel, T. (2009). A fistful of dollars: Lobbying and the financial crisis. International Monetary Fund Working Paper. http://dx.doi.org/10.5089/9781451874327.001

Jayachandran, S. (2006). The Jeffords effects. Journal of Law and Economics, 49(2), 397-425. http://dx.doi.org/10.1086/501091

Kilic, E., Lobo, G., Ranasinghe, T., \& Sivaramakrishnan, K. (2013). The Impact of SFAS 133 on Income Smoothing by Banks through Loan Loss Provisions, 88, 233-260. http://dx.doi.org/10.2308/accr-50264

Kostovetsky, L. (2015). Political capital and moral hazard. Journal of Financial Economics, 116, 144-159. http://dx.doi.org/10.1016/j.jfineco.2014.12.003

Liu, W., \& Ngo, P. (2014). Elections, political completion and bank failure. Journal of Financial Economics, 112, 251-268. http://dx.doi.org/10.1016/j.jfineco.2014.02.005

Nichols, D., Wahlen, J., \& Wieland, M. (2009). Publicly traded versus privately held: Implications for conditional conservatism in bank accounting. Review of Accounting Studies. 14, 88-122. http://dx.doi.org/10.1007/s11142-008-9082-3

Richter, B., Samphantharak., K., \& Timmmons, J. (2009). Lobbying and taxes. American Journal of Political Science, 53, 893-909. http://dx.doi.org/10.1111/j.1540-5907.2009.00407.x

Roberts, B.E. (1990). A dead senator tells no lies: seniority and the distribution of federal benefits. American Journal of Political Science, 34(1), 31-58. http://dx.doi.org/10.2307/2111510

Stratmannn., T. (1991). What do campaign contributions buy? Deciphering causal effects of money and votes. Southern Economic Journal, 57(3), 606-620. http://dx.doi.org/10.2307/1059776

Yu, F., \& Yu, X. (2011). Corporate lobbying and fraud protection. Journal of Financial and Quantitative Analysis, 46, 1865-1891. http://dx.doi.org/10.1017/S0022109011000457

\section{Note}

Note 1. I use SAS to estimate all regressions. 